real possibilities of a forensic examination that is its subject. In addition, the subject of the examination is proposed to recognize the circumstances that are relevant to the case and require timely establishment using the special knowledge of the expert in the relevant field of knowledge.

\title{
SOCIAL RIGHTS IN PRACTICE OF THE EUROPEAN COURT OF HUMAN RIGHTS
}

\section{Kateryna Denysenko ${ }^{1}$}

DOI: https://doi.org/10.30525/978-9934-588-84-6-12

Important tasks of the state in today's conditions are the following: incomplete process of democratization of Ukrainian society, searching for the optimal model of interaction of the state with socially vulnerable subjects, in particular those ones who have been exposed to social risk or are in difficult life circumstances, introduction of democratic standards and generally accepted European values, observance of rights, freedoms and guarantees of citizens who have experienced social risk or are in difficult life circumstances. Despite this fact, Ukraine's aspirations to join the European community as a full member are accompanied by the need to adjust national legislation in accordance with the norms of the European society, in particular in terms of observance and effective implementation of human and a citizen's social rights.

It is noteworthy that despite the significant development of modern science, there is still no generally accepted understanding of the category of «social rights». Thus, some scholars understand the concept of «social rights» as the ability of a person to realize their capabilities in order to ensure a decent standard of living and employment, as well as the ability to claim from the state certain material benefits [1, p. 40]. At the same time, others understand it as the rights to which a person has a direct right. This is expressed in the possibility of acquiring social benefits, their possessing, using and disposing as well as their protecting or taking certain actions in this area, as well as ensuring adequate social living conditions by guaranteeing and ensuring these rights by the state [2, p. 21].

\footnotetext{
${ }^{1}$ Academy of the State Penitentiary Service, Ukraine
} 
In each state, the direction, scope and essence of social rights are formed under the influence of a number of objective circumstances, primarily financial capacity and the level of development of current national legislation.

The Constitution of Ukraine enshrines a wide range of social rights and freedoms, which form a separate independent group in a single set of human and citizen's constitutional rights and freedoms, giving everyone the opportunity to protect their rights and freedoms from violations and unlawful encroachments by any means not prohibited by law [3]. Detailing of the constitutional norms regulating human and a citizen's social rights is carried out by means of developing the current social legislation. The dynamics of state and legal development leads to an increasing accumulation of regulations in various sectors of social sphere.

In practice, there are common cases in which there is a violation or disregard for citizens' social rights by both state institutions and their officials. The most effective mechanism for protecting and restoring violated social rights is the judiciary. In cases when all domestic remedies have been exhausted, necessitating additional mechanisms to protect violated rights, citizens can apply to international courts.

The point of view of the European Court of Human Rights concerning protection of citizens' social rights seems to be interesting for this purpose. Appealing to the above-mentioned judicial body is the last hope of many citizens for justice and a key means of restoring violated rights.

Article 17 of the Law of Ukraine «On Enforcement of Judgments and Application of the Case Law of the European Court of Human Rights» [4] stipulates that courts enforce the Convention for the Protection of Human Rights and Fundamental Freedoms and the case law of the Court as a source of law.

At the same time, the Convention and its Protocols do not contain direct norms that would enshrine social rights and mechanisms for their protection. Disputes on these issues are considered and resolved by the European Court of Human Rights by applying the articles that directly or indirectly relate to the protection of other rights.

Consequently, in the case «Suk ad versus Ukraine», in which, in accordance with the circumstances of the case, the applicant demanded that the former employer had to pay a delinquency in equivalent of monthly salary for two years, the European Court of Human Rights found a violation of Article 1 of Protocol No. 1 to the Convention [5]. It stipulates the following: «Every natural person or legal entity is entitled 
to the peaceful enjoyment of his possessions. No one shall be deprived of his possessions except in the public interest and subject to the conditions provided for by law and by the general principles of international law» [6].

In the case «Pichkur ad versus Ukraine», in which, in accordance with the circumstances of the case, the applicant, who was receiving a pension, emigrated to Germany and instructed his mother to receive the said payment. The Pension Fund of Ukraine found that the applicant no longer resided in Ukraine and stopped paying his pension. In that case, the Court found a violation of Article 14 of the Convention in conjunction with Article 1 of Protocol No. 1 (prohibition of discrimination and protection of property) as well as the obligation of the state-respondent to pay EUR 5,000 to the applicant in respect of pecuniary and non-pecuniary damage.

In the vast majority of cases related to the executing of citizens' social rights, the said Court ruled in favor of the plaintiffs, thereby recognizing violations of the Convention and its Protocols. In addition, a significant drawback of social rights protection through the ECtHR is the long-term proceedings. As practice shows, the vast majority of applicants in this group of cases are persons of retirement or old age and therefore the vast majority of them does not live till the moment of hearing the case.

\section{References:}

1. Volkova, O. M. (2011). Social rights of a person: concept, essence, features. Journal of Kyiv University of Law, issue 1, pp. 39-43.

2. Levytska, V. (2012). Theoretical interpretations of the essence of the concept of «social rights». Collection of scientific papers of the Odessa Regional Institute of Public Administration, issue 3(51), pp. 18-21.

3. The Constitution of Ukraine: Law of Ukraine dated 28.06.1996 № 254K/96-BP. Information of the Verkhovna Rada of Ukraine. 1996. № 30. Art. 141.

4. Law of Ukraine dated 23.02.2006 № 3477-IV «On execution of decisions and application of the case law of the European Court of Human Rights». URL: https://zakon.rada.gov.ua/laws/show/3477-15\#Text (accessed: 17.09.2020).

5. Judgment of the European Court of Human Rights dated 10.06.2011 «Suk ad versus Ukraine». URL: https://zakon.rada.gov.ua/laws/show/974_715 (accessed: 17.09.2020).

6. The First Protocol to the Convention for the Protection of Human Rights and Fundamental Freedoms dated 20.03.1952. URL: https://zakon.rada.gov.ua/laws/ show/994_535 (accessed: 17.09.2020).

7. Judgment of the European Court of Human Rights dated 07.11.2013 «Pichkur ad versus Ukraine». URL: https://zakon.rada.gov.ua/laws/show/974_984 (accessed: 17.09.2020). 